\title{
Persistence of fire-killed conifer snags in California, USA
}

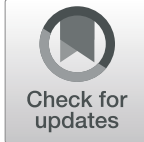

Lindsay M. Grayson", Daniel R. Cluck² and Sharon M. Hood ${ }^{1 *}$ (D)

\begin{abstract}
Background: Coarse woody debris has numerous functions in forest ecosystems, including wildlife habitat, fuel loading, and nutrient cycling. Standing dead trees, or snags, are particularly important resources for wildlife, and guidelines for snag recruitment and retention are integral parts of forest management. However, snag persistence is not well understood and existing models are poorly validated. We monitored fire-killed conifer snag persistence after four California wildfires and one prescribed fire. Species sampled included white fir (Abies concolor [Gord. \& Glend.] Lindl. ex Hildebr.), incense-cedar (Calocedrus decurrens [Torr.] Florin), Jeffrey pine (Pinus jeffreyi [Balf.]), sugar pine (Pinus lambertiana Douglas), and ponderosa pine (Pinus ponderosa Lawson \& C. Lawson var. ponderosa C. Lawson).

Results: Fire-injured trees that survived at least one year post fire were monitored for 10 years after they died. We developed two sets of species-specific snag persistence rates: a simplified model based only on time since death, and a full model that included tree characteristics. The primary factors affecting persistence rates in all models were snag age (years since death) and species. Secondary factors included diameter at breast height, time between fire and tree death, and crown injury. Snag persistence rates decreased with snag age. Yellow pine snags (a combined group of ponderosa pine and Jeffrey pine) fell significantly faster than any other species. Larger-diameter snags persisted longer than smaller-diameter snags for all species. Incense-cedar trees that survived longer post fire persisted longer as snags.
\end{abstract}

Conclusions: This study provides land managers with guidance on snag longevity, which can aid in planning for long-term wildlife habitat, fuel loading estimates, and forest structural diversity.

Keywords: FFE-FVS, model evaluation, model validation, snag dynamics, snag longevity

\footnotetext{
* Correspondence: sharon.hood@usda.gov

'USDA Forest Service, Rocky Mountain Research Station, Fire, Fuel, and Smoke Science Program, 5775 US Highway 10 W, Missoula, Montana 59808,

USA

Full list of author information is available at the end of the article
}

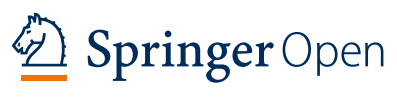

(c) The Author(s). 2021, corrected publication 2021. Open Access This article is licensed under a Creative Commons Attribution 4.0 International License, which permits use, sharing, adaptation, distribution and reproduction in any medium or format, as long as you give appropriate credit to the original author(s) and the source, provide a link to the Creative Commons licence, and indicate if changes were made. The images or other third party material in this article are included in the article's Creative Commons licence, unless indicated otherwise in a credit line to the material. If material is not included in the article's Creative Commons licence and your intended use is not permitted by statutory regulation or exceeds the permitted use, you will need to obtain permission directly from the copyright holder. To view a copy of this licence, visit http://creativecommons.org/ licenses/by/4.0/. 


\section{Resumen}

Antecedentes: Los residuos leñosos gruesos tienen numerosas funciones en los ecosistemas forestales, incluyendo el hábitat para la fauna, la carga de combustibles y el ciclado de nutrientes. Los árboles muertos en pié (snags de ahora en más) son un recurso particularmente importante para la fauna silvestre, siendo las guías para su reclutamiento y retención parte integral del manejo forestal. Por supuesto, la persistencia de estos snags no es aún bien comprendida, y los modelos existentes pobremente validados. Monitoreamos la persistencia de snags de diferentes coníferas muertas por efectos de fuegos naturales y de una quema prescripta en California. Las especies de coníferas incluían el abeto del Colorado (Abies concolor [Gord. \& Glend.] Lindl. ex Hildebr.), el cedro blanco de California (Calocedrus decurrens [Torr.] Florin), el pino Jeffrey (Pinus jeffreyi [Balf]]), el pino lambertiana (Pinus lambertiana Douglas), y el pino ponderosa (Pinus ponderosa Lawson \& C. Lawson var. ponderosa C. Lawson).

Resultados: Los árboles dañados por el fuego y que sobrevivieron al menos durante el primer año post-fuego fueron monitoreados luego por 10 años posteriores a su muerte. Desarrollamos dos modelos de tasas de persistencia especie-específicas para los snags: un modelo simple basado solo en el tiempo ocurrido desde su muerte, y otro más completo que incluía las características de los árboles. Los factores primarios que afectaron las tasas de persistencia fueron la edad de los snags (años desde su muerte), y especies. Los factores secundarios incluyeron el diámetro a la altura del pecho (DBH), el tiempo entre el evento de fuego y la muerte del árbol, y los daños en la corona. Las tasas de persistencia de los snags decreció con la edad del snag. Los snags de los llamados pinos amarillos (un grupo combinado de pino ponderosa y pino Jeffrey) cayeron más rápido que cualquier otra especie. Los snags de mayor diámetro persistieron por más tiempo que los de menor diámetro para todas las especies. Los cedros blancos de California que sobrevivieron al post-fuego por más tiempo, también persistieron más tiempo luego como snags.

Conclusiones: Este estudio provee a los administradores de recursos de una guía sobre la longevidad de los snags, que puede ayudarlos a planificar sobre el habitat para la fauna a largo plazo, la estimación de carga de combustibles y la diversidad estructural del bosque.

\section{Background}

Dead trees are an important component of forest ecosystems. Either as standing snags or downed logs, they play vital roles in nutrient cycling and in carbon sequestration (Harmon et al. 1986; Krankina and Harmon 1995; Brais and Paré 2006). They also provide habitat and foraging sites for vertebrates and invertebrates, as well as growth sites for fungi, lichen, and bryophytes (Thomas 1979; Harmon et al. 1986; Bunnell and Kremsater 1990; Bull and Parks 1997). In the northwestern United States, about $9 \%$ of all wildlife species and over $25 \%$ of bird species utilize dead trees (R. Harger, USDA Forest Service, Northern Region, Missoula, Montana, USA, unpublished report; McClelland et al. 1979, Hicks 1983). At least 169 wildlife species in California utilize snags (California Department of Fish and Wildlife 2014). Nearly all snags larger than $10 \mathrm{~cm} \mathrm{DBH}$ (diameter at breast height; $1.37 \mathrm{~m}$ above ground) can be used, although some wildlife species prefer specific tree species or sizes (Thomas 1979; Parish et al. 2010). In general, larger snags can support more wildlife species, though a diversity of snags with varying $\mathrm{DBH}$, height, decay class, and species is important to manage for a wide variety of wildlife (Raphael and White 1984; Bunnell 2013).
Predicting snag longevity is important in many aspects of forest management, from quantifying habitat requirements, carbon stores, and fuel loading, to identifying safety hazards. Despite this importance, snag dynamics are still poorly understood. Studies have identified many different and often discrepant factors affecting snag persistence. Most studies have found snag age (i.e., time since death), and species significantly affect snag persistence, with some overlap between similar species. While most studies report that snag diameter affects longevity, with larger snags persisting longer than smaller snags (Keen 1955; Bull 1983; Raphael and Morrison 1987; Chambers and Mast 2005), some studies have found no impact of DBH (Schmid et al. 1985; Harrington 1996). Other factors including cause of death, tree height, soil type, site aspect, slope, microclimate, species composition, landform, salvage harvesting, and stand density have been identified as significant in some studies, but not significant in others (Keen 1955; Lyon 1977; Mitchell and Preisler 1998; Russell et al. 2006; Parish et al. 2010). Large-scale factors such as climate may also play an important role, but lack empirical evidence to describe their effects (Keen 1955; Harmon et al. 1986; Garber et al. 2005). In addition to these studies, the Fire and Fuels Extension of the Forest Vegetation Simulator 
(FFE-FVS), a commonly used forest growth model, includes submodels of snag dynamics (Reinhardt and Crookston 2003). These snag submodels are largely not validated, although a few have incorporated work from the Snag Recruitment Simulator and the Coarse Woody Dynamics Model (Marcot 1992; Mellen and Ager 2002).

Wildland fire burns millions of forested hectares annually in the western United States (National Interagency Fire Center: https://www.nifc.gov/fireInfo/nfn.htm) and is a major cause of snag recruitment (Raphael and White 1984). Several studies indicate that the snag longevity of fire-killed trees is different than other causes of mortality (Raphael and Morrison 1987; Everett et al. 1999; Garber et al. 2005), although few exist that directly compare snags created by fire versus other means (Raphael and Morrison 1987; Morrison and Raphael 1993; Chambers and Mast 2005). Most suggest that fire-killed snags persist for less time than snags created by other mortality agents. These fire-killed snags persist for only a short time, with very few remaining after 10 years (Harrington 1996; Everett et al. 1999; Ritchie et al. 2013; Ritchie and Knapp 2014). Current post-fire management practices often include harvest activities to recoup economic losses from dead trees, to reduce long-term coarse woody fuel loading, and for hazard-tree abatement (Dunn and Bailey 2015; Peterson et al. 2015). Snag retention guidelines frequently focus on tree sizes and species anticipated to persist the longest. Improved understanding of post-fire snag persistence is needed to better predict long-term fire effects and to ensure that forest management objectives for snag density are met.

We monitored trees from five species for 10 years after death in four wildfires and one prescribed fire in California, USA, which burned between 2000 and 2004. There are limited studies on the snag dynamics of fire-killed trees, and even fewer that include the species monitored here or that account for tree-level fire injuries (Table 1). Our objectives were: (1) to quantify post-fire snag persistence, (2) to determine which snag characteristics most affect persistence, and (3) to evaluate the predictive accuracy of the snag submodel in FFE-FVS.

\section{Methods}

\section{Study area and sampling}

The data and sampling methods used here are largely a subset of those described in detail in Hood et al. (2010), which were used to develop post-fire tree mortality models. Briefly, we sampled in five burned areas (Cone, McNally, Power, and Storrie wildfires, and Prattville prescribed burn) across a wide geographical area in California extending from the southern end of the Cascade Range to the southern end of the Sierra Nevada mountain range. All fires except Prattville, a mixed-severity prescribed fire, were reported in Hood et al. (2010).
These areas burned between 2000 and 2004. All fires were in the Sierra Nevada mixed-conifer forest type (SAF Type 243; Tappeiner 1980) with the exception of the Cone Fire, which occurred in the interior ponderosa pine type (SAF Type 237; Barrett et al. 1980). Personnel from local forest districts identified areas of mixedseverity fire within each fire boundary for possible sampling sites. These areas burned primarily as surface fires, with the majority of trees retaining some green needles. Species sampled included white fir (Abies concolor [Gord. \& Glend.] Lindl. ex Hildebr.), incense-cedar (Calocedrus decurrens [Torr.] Florin), Jeffrey pine (Pinus jeffreyi [Balf.]), sugar pine (Pinus lambertiana Douglas), and ponderosa pine (Pinus ponderosa Lawson \& C. Lawson var. ponderosa C. Lawson).

We selected trees during the summer of the year following each fire based on categorical bins in an effort to assess a full range of tree and injury characteristics. Specific categories included DBH classes from 25 to $50 \mathrm{~cm}$, 51 to $76 \mathrm{~cm}$, and $\geq 77 \mathrm{~cm}$; crown kill ranges $\leq 10 \%, 11$ to $50 \%, 51$ to $60 \%, 61$ to $70 \%, 71$ to $80 \%, 81$ to $90 \%$, and 91 to $100 \%$; and cambium kill categorical ratings of $0,1,2$, 3 , and 4. Any tree that survived at least one year post fire was monitored annually for five years or until death, then for 10 years post mortality. Only trees with 10 years of post-mortality observations were used in this analysis. One year post fire, we assessed tree and injury characteristics including species, DBH, tree height, pre-fire crown length, number of red turpentine beetle (RTB; Dendroctonus valens LeConte) pitch tubes for pines, and fire injury. We quantified fire injury by recording cambium kill rating (CKR; ordinal variable between 0 and 4 describing the number of dead cambium samples at each quadrant of the tree base), crown length killed (all species; observed portion of the crown with dead tissue from fire injury), and crown length scorched (Jeffrey pine and ponderosa pine only; observed portion of the crown with dead needles, but living buds and branches). Lengths were measured using a clinometer or laser hypsometer to the nearest $0.3 \mathrm{~m}$. We calculated pre-fire crown length and crown length killed from the estimated prefire crown base height, post-fire crown base height, and tree height measurements. The pre-fire crown was estimated using the methods described in Ryan (1982), by visually reconstructing the crown to its pre-fire state based on crown scorch and fine branch structure. We converted crown length killed into percent crown length killed, by dividing the crown length killed by the pre-fire crown length to create a crown injury variable $(\mathrm{CI})$. When crown length killed was not available, we used an estimated live crown measurement to determine percent crown length killed. Snag persistence may be influenced by whether it is in isolation or in a group of living trees (Mitchell and Preisler 1998; Russell et al. 2006). We 


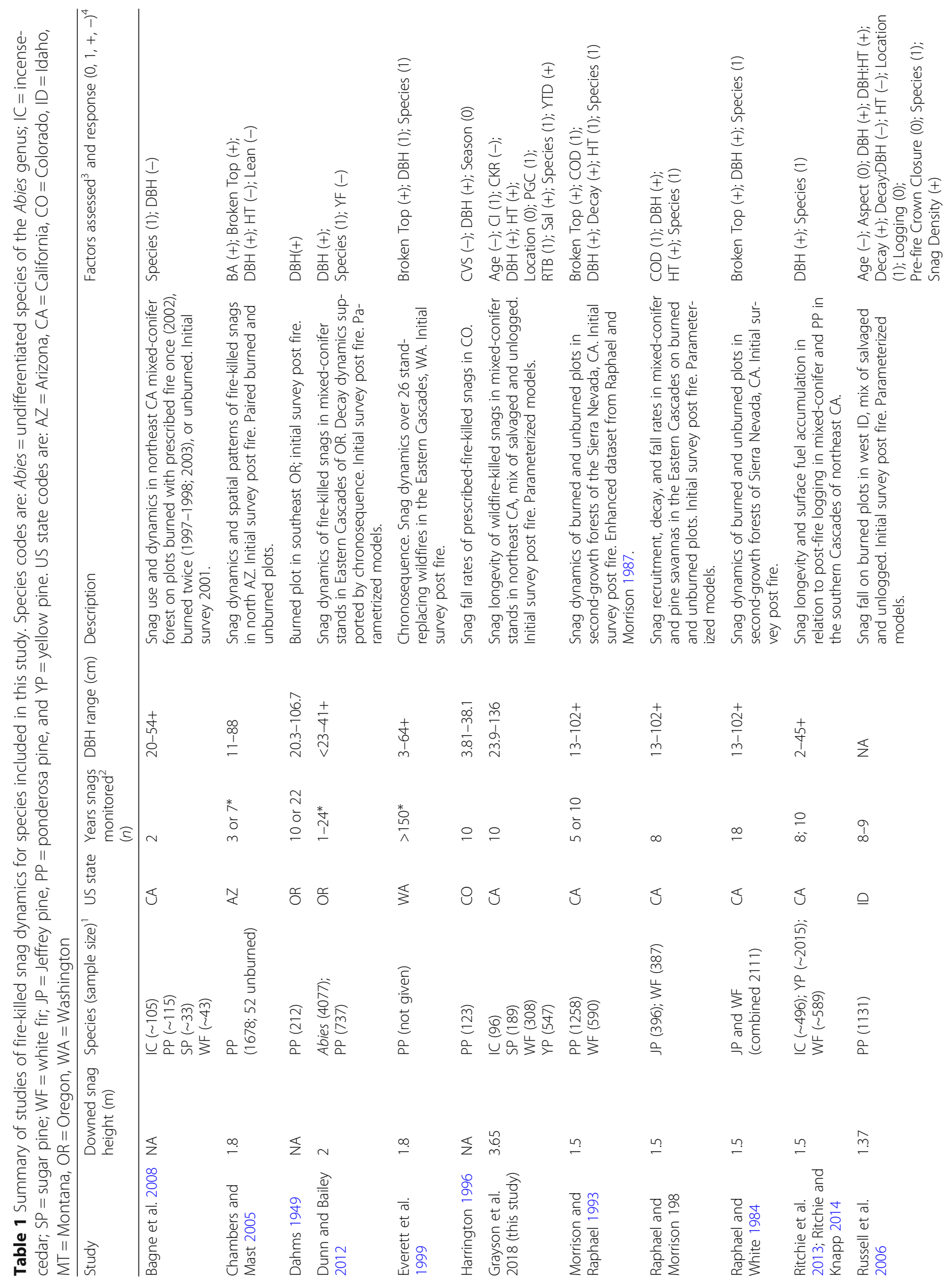




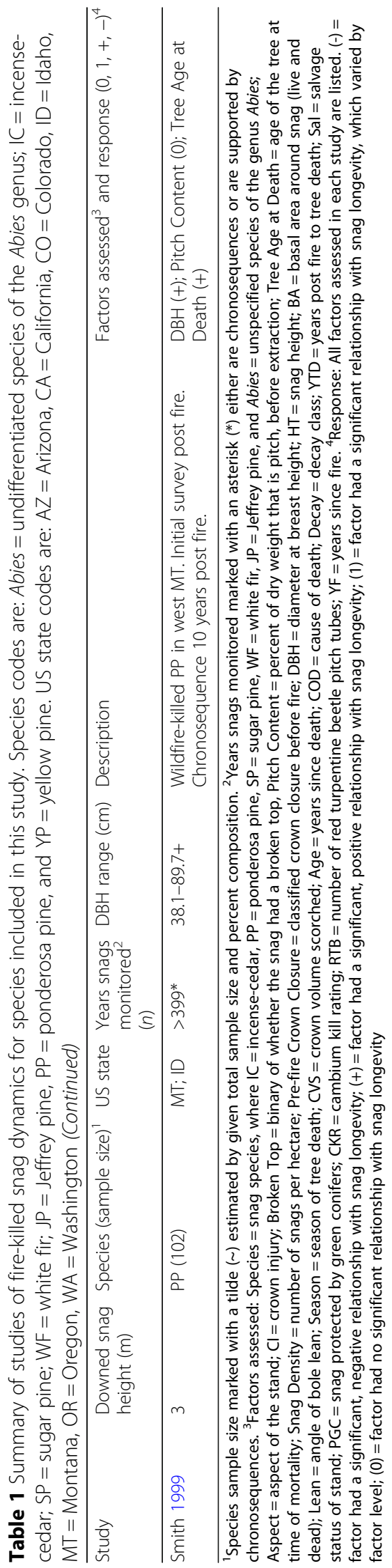


therefore also assessed whether each snag was in a stand that had been salvage logged (Sal) and if the snag was surrounded by live conifers (protected by green conifers; PGC) as binary categories $(0=$ no and $1=$ yes $)$. Each year after this initial assessment, trees were monitored for live or dead status and break height, if applicable.

Snags were monitored until they fell or broke below $3.65 \mathrm{~m}$. This threshold was chosen as a combination of the taller snag requirements in the Lassen National Forest Resource Management Plan (USDA Forest Service 1992), which recommends that suitable wildlife snags be at least $6.1 \mathrm{~m}$ tall, and studies of snag nesting heights and foraging use that suggest shorter snags are poorly utilized. For example, Ganey (2016) found that snags of $3 \mathrm{~m}$ or more held $95 \%$ of nesting cavities. In a monograph of 18 cavity-nesting bird species in the Sierra Nevada, California, mean nest snag height was $12.3 \mathrm{~m}$ for all species combined and the lowest individual species mean nest snag height was $3.8 \mathrm{~m}$ (Raphael and White 1984). In a review of snag use by mammals and birds, only one bird species had a mean nest height shorter than $5 \mathrm{~m}$ (Bunnell et al. 2002). Ponderosa pine and Jeffrey pine were combined into one group during data collection and are referred to as yellow pine hereafter.

\section{Analysis}

Descriptive analyses by standing and downed snag categories were performed for each species, including range, mean, and standard error of the mean for DBH, $\mathrm{CI}$, and YTD (time between the year of the fire and the year of tree death). These were compared within and among species using a Wilcoxon rank-sum test to determine if there was a difference between the characteristics of downed and standing snags. With this and all other analyses, a $P$-value of less than 0.05 was used to define statistical significance unless otherwise noted. Preliminary results showed marked species differences; we therefore evaluated species separately. Analyses were performed with the R Statistical Program v. 3.3.1 (R Development Core Team. 2016).

\section{Data censoring}

Snags were evaluated for 10 years after death. Over 35\% of the snags were still standing by the end of the observation period. These snags were considered rightcensored (i.e., snags were followed for a set amount of time rather than until all snags in our sample population fell). In addition to the right-censoring, several snags had years in which they were not measured. If these snags were standing before the missed observation, but down at the next observation, the censoring was assumed to be non-informative and those snags were considered to be standing for the missing years. This is the standard protocol for such interval censoring (Kleinbaum and Klein 2010).

\section{Snag longevity trends}

We first fit unique models to each species for both overall persistence rates and individual fall risk using time since fire as the only independent variable (time-only model). The time-only models can be used to estimate stand-level snag persistence. We fit five common distributions-Weibull, exponential, logistic, log-logistic, and Gaussian-to each species' persistence time to determine the general shape before developing final time-only models. When comparing maximum log-likelihood, Weibull and log-logistic were the top models for all species. However, the likelihood ratio was not significantly different for the two distributions in the case of incensecedar. We chose to use the Weibull function because the heavier tail predicted with the log-logistic distribution cannot be evaluated within the timeframe of our observations and because the hazard function, or the probability that a snag will fall within the next time unit (in this case, one year) given it has survived until a certain time, is monotonically increasing for the Weibull distribution (where the shape parameter is greater than 1 ), but is nonmonotonic (first increasing, then decreasing) for log-logistic distributions. Ecologically, the older a snag is, the more likely it is to fall before the next observation, making the Weibull function a more logical fit. To ensure that differences in average DBH between species in our sample were not confounding the timeonly models, we also fitted species-specific models using a subset of snags centered on a mean of $52 \mathrm{~cm} \mathrm{DBH}$ and compared to the time-only models with the full datasets. The plotted curves exhibited similar trends (data not shown).

Weibull curves can be parameterized in several different ways to achieve equivalent results. For the survival analysis to predict the standing time of a snag after death, we used the accelerated failure time (AFT) model (Eqs. 1-3; Qi 2009) rather than the proportional hazards model. Although both forms use the same standard notation, the parameter interpretations are not equivalent. The resulting AFT parameters can be used to determine the hazard of falling from one year to the next, the probability of persistence to a certain age, and the age of snag-fall given a certain probability threshold. In the AFT model, the covariate accelerates or decelerates the life course (i.e., how much time passes before a snag transitions from standing to fallen) by a constant. In addition, parameter coefficient estimates in AFT regressions are robust to unknown, unaccounted for covariates and are not strongly affected by probability distribution choice. 
Equation 1 is the percentile of survival $(S)$ at a given time $(t)$,

$$
S(t)=\exp \left[-\exp \left(\frac{-\mu-\alpha^{\prime} x}{\sigma}\right) t^{\frac{1}{\sigma}}\right]
$$

where,

$$
\begin{aligned}
& S=\text { standing snag persistence rate (i.e., survival rate) } \\
& t=\text { time } \\
& \mu=\text { intercept } \\
& \sigma=\text { scale parameter } \\
& \alpha^{\prime} x=\left(\alpha_{1} x_{1}+\alpha_{2} x_{2}+\ldots+\alpha_{i} x_{\mathrm{i}}\right) \text {, where } \alpha=\text { covariate } \\
& \text { coefficients and } x=\text { covariates (e.g., DBH, CI, YTD). }
\end{aligned}
$$

Equation 2 is the hazard rate $(h)$ at a given time $(t)$ using the same variables as Eq. 1:

$$
h(t)=\frac{1}{\sigma} t^{\frac{1}{\sigma}}-1 \exp \left(\frac{-\mu-\alpha^{\prime} x}{\sigma}\right)
$$

Equation 3 is survival time $(t)$ given a percentile $(p)$ of the survival distribution:

$$
t(p)=\exp \left[\sigma \log \left\{-\log \left(\frac{100-p}{100}\right)\right\}+\mu+\alpha^{\prime} x\right]
$$

\section{Factors affecting snag longevity}

We next developed individual snag-persistence equations with time since fire and additional covariates as independent variables (covariate model) through a combination of purposeful variable selection, model averaging, and information theoretic selection. Variables tested as covariates included CKR, DBH, CI, RTB, PGC, YTD, snag height, and species. The covariate models can be used to identify specific individual snags within a stand that are likely to persist the longest. Preliminary main effects variables were chosen by univariate significance $(P<0.25)$ or known ecological importance, then narrowed to those that were statistically and logically conditionally independent from other variables. We additionally assessed the impact of random effects of individual variability and fire (e.g., location) on snag persistence. A full model was then developed using model averaging to determine the suite of models that had the best Akaike's information criterion (AIC). Model-averaged importance of terms and model weights were calculated. All variables with importance greater than 0.8 were included, and any terms included in the models as a covariate but not as a variate were included as the latter for interpretability. Although these averaged models provided the likely best predictive model, they are less interpretable and tend to have many more terms than a more practical model. Terms were thus selected from these full equations using both a backward and a stepwise AIC procedure until the difference in AIC of the simpler model and the full model fell to less than 7 (Anderson and Burnham 2002; Burnham et al. 2011). We chose a model from this suite of best models for each species that maximized accuracy, goodness of fit, and simplicity, while utilizing the most reliable and easy to collect variables. Following term selection, the models were bootstrapped with a set seed 2500 times with 20\% replacement to estimate coefficients. Estimates are the median bootstrap value minus the bias estimate. Estimated stand-level persistence was calculated using the median values of each covariate. The estimated probability of persistence at year 10 was calculated for each individual snag to assess the accuracy of the models. Snags with a probability of persistence greater than or equal to 0.5 (i.e., $\geq 50 \%$ chance of snag persisting through a given year) at year 10 were considered predicted to be standing and those with a probability of persistence less than 0.5 were considered predicted to be down.

\section{FFE-FVS snag submodel evaluation}

The Forest Vegetation Simulator (FVS) is widely used to predict stand dynamics in response to time, management, disturbance, and natural succession. The FFE-FVE integrates FVS with models of fuel dynamics, fire behavior, and fire effects. In addition, it includes a snag submodel to predict the breakage, decay, and persistence rates of snags based on snag height, decay status, diameter class, and a species- and variant-specific fall rate multiplier. The last $5 \%$ of snags in a stand are predicted to fall at a rate of 0.01 per year, with a maximum persistence of 100 years (Reinhardt and Crookston 2003). Other than this change, FFE-FVS does not account for snag age when calculating persistence rates. FFE-FVS does not take cause of mortality into account, although there is an option to simulate a fire in the snags. The snags in this study were from two variants of FVS: Inland California and Southern Cascades (ICASCA) and Western Sierra Nevada. The fall rate multipliers for these variants are the same when rounded to two decimal places, at 0.69 for incense-cedar, 0.88 for white fir, and 1.24 for yellow pine and sugar pine. We compared observed yearly cumulative snag persistence to those predicted by FFE-FVS.

\section{Results}

A total of 1140 snags were followed for 10 years after death: 96 incense-cedar, 189 sugar pine, 308 white fir, and 547 yellow pine. At 10 years post mortality, $13 \%$ of incense-cedar, $42 \%$ of sugar pine, $46 \%$ of white fir, and 95\% of yellow pine had fallen (Figs. 1 and 2). Average initial break heights were similar across species examined: $0.6 \mathrm{~m}$ for incense-cedar, $3.5 \mathrm{~m}$ for sugar pine, 


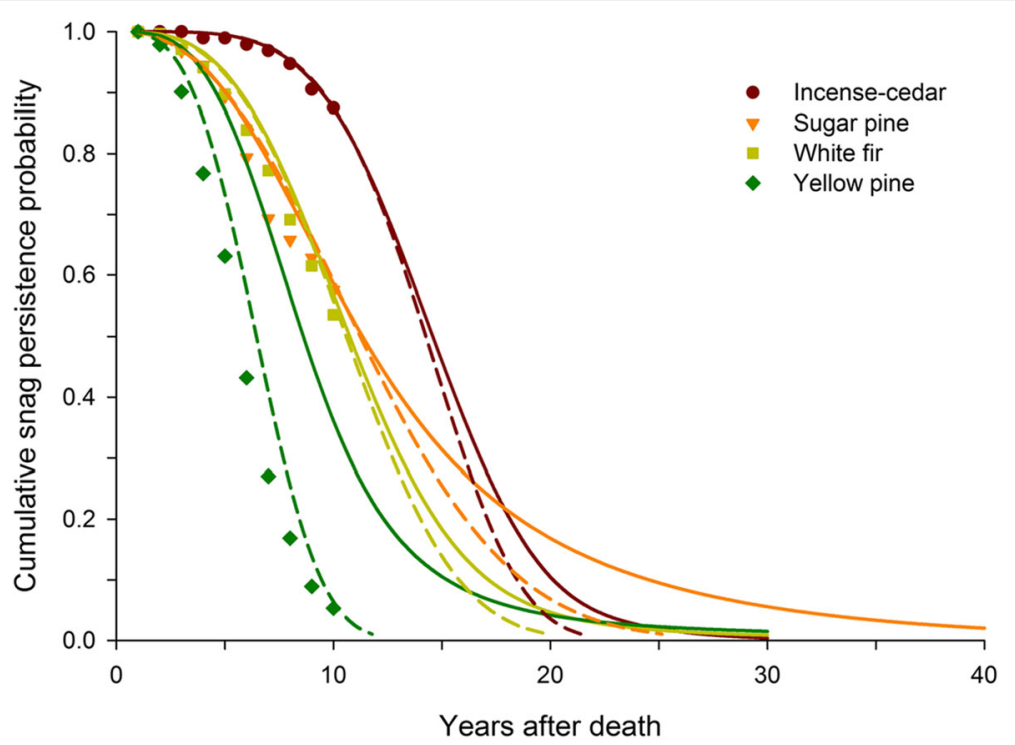

Fig. 1 Observed and predicted snag persistence once a tree dies from wildfire ( $1=$ standing; 0 = downed or $<3.65 \mathrm{~m}$ tall) by species. Fire-killed tree data were collected from five fires in California that were monitored for 10 years after death. Symbols are observed values, dashed lines are predicted values from time-only models, and solid lines are predicted values from full covariate models

$3.2 \mathrm{~m}$ for white fir, and $1.0 \mathrm{~m}$ for yellow pine. Of the 869 snags that broke during the 10 years that they were followed, 613 snags $(71 \%)$ broke at groundline. All species datasets covered the full range of fire-caused injuries and a wide range of diameters (Table 2). We only report summary statistics for variables that were significant in the best models; these included DBH, CI, and YTD (Table 2), and PGC. Standing sugar pine (DBH: $P<$ 0.0001 ), white fir (DBH: $P<0.0001$ ), and yellow pine (DBH: $P=0.001$ ) were larger than downed snags, but DBH did not differ between standing and downed incense-cedar $(P=0.298)$. PGC did not differ between standing and downed snags of any species $(P>0.05)$ : $95 \%$ of standing and $100 \%$ of downed incense-cedar, $77 \%$ of standing and $79 \%$ of downed sugar pine, $89 \%$ of standing and $93 \%$ of downed white fir, and $53 \%$ of standing and $45 \%$ of downed yellow pine snags were protected by green conifers. Crown injury did not differ for any species between standing and downed snags (CI: $P>$ 0.05 ). Incense-cedar (YTD: $P=0.026$ ) and yellow pine (YTD: $P=0.028$ ) trees that survived longer post fire persisted longer as snags, while YTD was not different

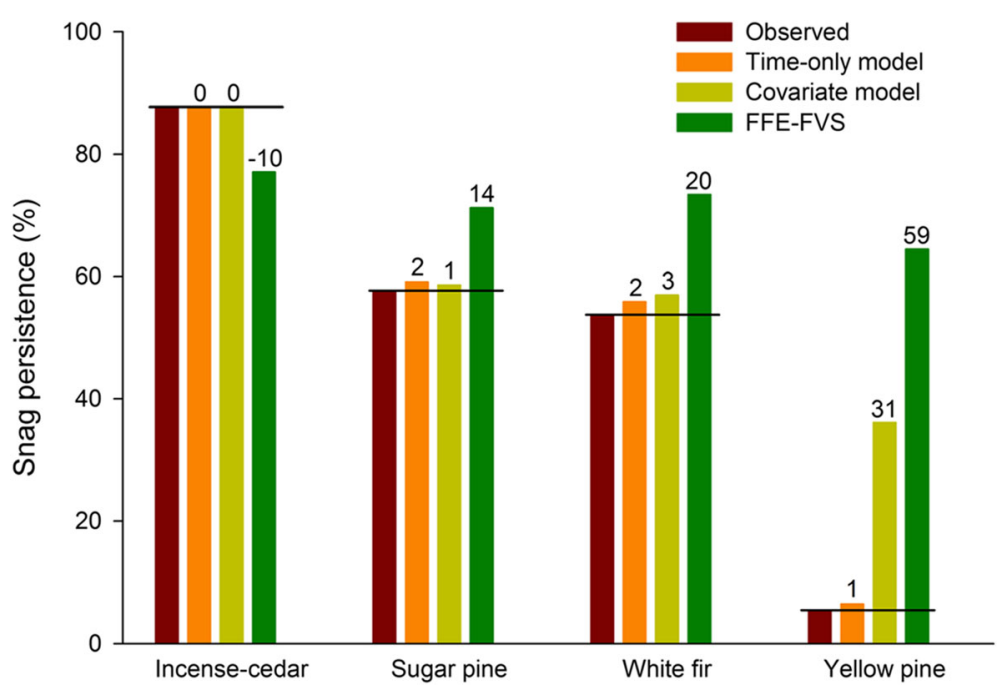

Fig. 2 Observed percentage of snags persisting 10 years after death by species compared to model predicted values. Fire-killed tree data were collected from five fires in California that were monitored for 10 years after death. Black bars compare differences in predicted values from observed. Numbers are over- or under-predicted percentages from observed 
Table 2 Descriptive analysis of diameter at breast height (DBH), crown injury percent (CI), and years to death post fire (YTD) by species and status. Species codes are: IC = incense-cedar; SP = sugar pine; WF = white fir; and YP= yellow pine. Status of 0 is standing and status of 1 is fallen at year 10. P-values are for Wilcoxon signed rank tests. SE = standard error

\begin{tabular}{|c|c|c|c|c|c|c|c|c|c|c|}
\hline \multirow[t]{2}{*}{ Species } & \multirow{2}{*}{$\begin{array}{l}\text { Status at year } \\
10(n)\end{array}$} & \multicolumn{3}{|l|}{$\mathrm{DBH}(\mathrm{cm})$} & \multicolumn{3}{|l|}{$\mathrm{Cl}(\%)$} & \multicolumn{3}{|c|}{ YTD (years) } \\
\hline & & Range & Mean (SE) & $P$-value & Range & Mean (SE) & $P$-value & Range & Mean (SE) & $P$-value \\
\hline \multirow[t]{2}{*}{ IC } & Standing (84) & $25.7-113.3$ & $47.5(2.2)$ & 0.298 & 8.7-97.9 & $78.2(2)$ & 0.727 & $0-3$ & $1.0(0.1)$ & 0.026 \\
\hline & Fallen (12) & $28.7-98.3$ & $41.8(5.6)$ & & 53.6-97.2 & $82.1(3.4)$ & & $0-2$ & $0.6(0.2)$ & \\
\hline \multirow[t]{2}{*}{$\mathrm{SP}$} & Standing (113) & $30.0-141$ & $73.9(2.3)$ & 0.001 & $0.0-97.9$ & $54.6(2.4)$ & 0.209 & $1-3$ & $2.4(0)$ & 0.401 \\
\hline & Fallen (76) & $25.7-98.8$ & $51.7(1.7)$ & & $0.0-98.3$ & $58.9(3)$ & & $1-3$ & $2.3(0.1)$ & \\
\hline \multirow[t]{2}{*}{ WF } & Standing (171) & $25.4-136$ & $55.9(1.5)$ & $<0.001$ & $0.0-97.1$ & $75.6(1.4)$ & 0.321 & $0-4$ & $1.4(0.1)$ & 0.727 \\
\hline & Fallen (137) & 25.4-91.8 & $45.8(1.2)$ & & $2.4-97.5$ & 73.9 (1.6) & & $0-4$ & $1.4(0.1)$ & \\
\hline \multirow[t]{2}{*}{ YP } & Standing (40) & $27.7-112.8$ & $65.0(3.8)$ & 0.001 & $0.0-100$ & $81.3(2.9)$ & 0.157 & $0-4$ & $1.4(0.2)$ & 0.028 \\
\hline & Fallen (507) & $23.9-131.8$ & $52.2(0.8)$ & & $0.0-100$ & $83.0(1)$ & & $0-4$ & $1.0(0)$ & \\
\hline
\end{tabular}

between sugar pine (YTD: $P=0.401)$ nor white fir $(P=$ 0.727 ) standing and downed snags.

\section{Persistence trends}

There were clear differences in species in snag persistence (Fig. 1; symbols show observed values). Yellow pine fell fastest and incense-cedar persisted the longest. Sugar pine and white fir persistence rates were similar to each other and fell in between yellow pine and incense-cedar. The models fit for each species all differed from each other in scale, shape, or both, indicating that snag dynamics required species-specific equations (Fig. 1; Table 3). The first set of models predicted persistence rates by only accounting for time since fire (Fig. 1; dashed lines). The models estimated that $50 \%$ of snags would fall by 7 years after dying for yellow pine, 10 years for white fir, 11 years for sugar pine, and 14 years for incense-cedar. They predicted that $99 \%$ of snags would fall by 21 years for incense-cedar, 25 years for sugar pine, 20 years for white fir, and 12 years for yellow pine after dying. Although incense-cedar displayed the greatest lag time in persistence drop-off, the snag fall after this initial lag increased rapidly. In contrast, sugar pine snags initially fell faster than incense-cedar and at a similar rate to white fir, but the model estimated the rate of fall to slow over time, leading to a small portion of the snags persisting for $>25$ years after dying from fire. White fir displayed a moderate lag at both the beginning and end of the life cycle. Yellow pine showed almost no lag at the beginning or end of the snag life cycle; snag persistence probability decreased rapidly and consistently.

Table 3 Coefficient estimates of regressions (from Eqs. 1-3: $a_{1}, a_{2}$, etc., are the covariate coefficients corresponding to $x_{1}, x_{2}$, etc.; $\mu$ is the intercept; and $\sigma$ is the scale); coefficient standard error estimate in parentheses. Variable codes are: diameter at breast height $(\mathrm{DBH} ; \mathrm{cm})$; crown injury percent $(\mathrm{Cl})$; years to mortality post fire (YTD), and protected by green conifers (PGC; $0=$ no and $1=$ yes) by species and status. Species codes are: $\mathrm{IC}=$ incense cedar; $\mathrm{SP}=$ sugar pine; $\mathrm{WF}=$ white fir; and $\mathrm{YP}=$ yellow pine. Superscript numbers indicate model-averaged variable importance rank. $\triangle \mathrm{AIC}$ is the difference between this model and the best AIC model. Those terms that are less than 0.8 in model-averaged importance are noted with an asterisk $\left(^{*}\right)$

\begin{tabular}{|c|c|c|c|c|c|c|c|c|}
\hline \multirow[b]{2}{*}{ Species } & \multicolumn{4}{|c|}{ Covariate Models } & \multicolumn{4}{|l|}{ Time-only } \\
\hline & $\mathrm{IC}$ & $\mathrm{SP}$ & WF & YP & $\overline{Y P}$ & $\mathrm{SP}$ & WF & IC \\
\hline$\triangle \mathrm{AIC}$ & 6.7 & 3.8 & 0.4 & 0.05 & & & & \\
\hline Scale & $0.2148(0.0011)$ & $0.3835(0.0334)$ & $0.3184(0.025)$ & $0.2946(0.0098)$ & $0.3181(0.0104)$ & $0.4252(0.0366)$ & $0.3323(0.0257)$ & $0.2104(0.0756)$ \\
\hline Intercept & $2.3333(0.1875)$ & $1.5084(0.1618)$ & $0.9633(0.3302)$ & $0.6394(0.1841)$ & 1.9812 & 2.5754 & 2.4821 & 2.7368 \\
\hline $\mathrm{DBH}$ & & $0.0173(0.003)$ & $0.0290(0.0079)^{1}$ & $0.0457(0.0090)^{1}$ & & & & \\
\hline $\mathrm{Cl}$ & & & $0.0141(0.0043)^{2}$ & $0.0164(0.0028)^{1}$ & & & & \\
\hline PGC & & & & $0.6026(0.1262)^{4}$ & & & & \\
\hline YTD & $0.2250(0.0975)$ & & & & & & & \\
\hline $\mathrm{Cl}: \mathrm{DBH}$ & & & $-0.0003(0.0001)^{3}$ & $-0.0005(0.0001)^{3}$ & & & & \\
\hline Cl: PGC & & & & $-0.0058(0.0018)^{5}$ & & & & \\
\hline PGC: DBH & & & & $-0.0082(0.0046)^{6 *}$ & & & & \\
\hline
\end{tabular}




\section{a Incense-cedar}

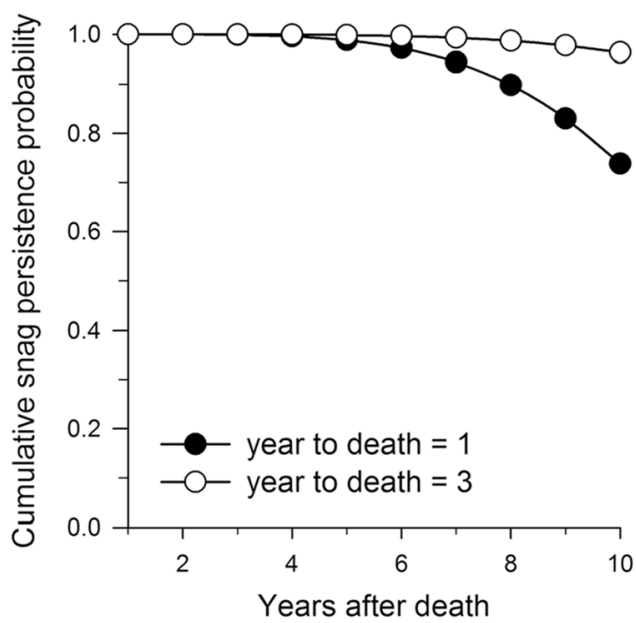

\section{b Sugar pine}

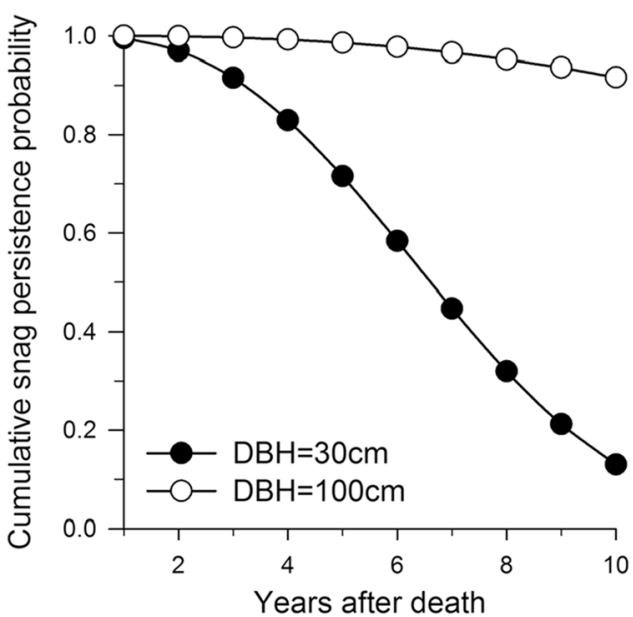

c White fir

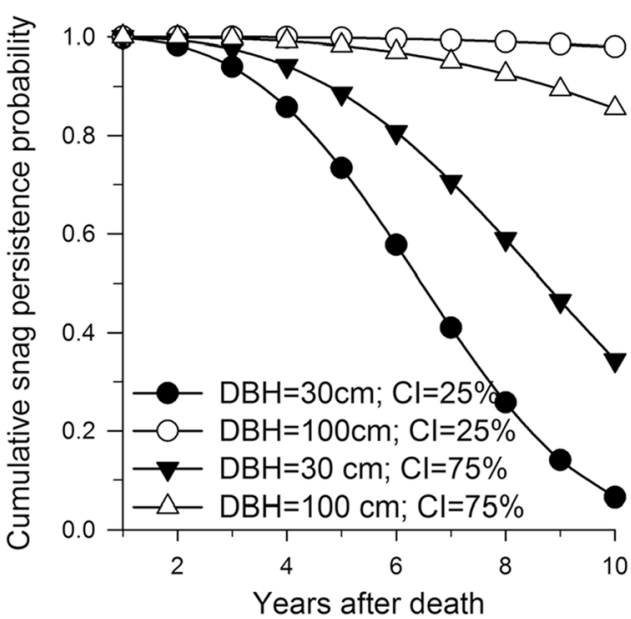

Fig. 3 Sample predicted snag persistence once a tree dies from wildfire ( 1 = standing; 0 = downed or $<3.65 \mathrm{~m}$ tall) from covariate models for (a) incense-cedar, (b) sugar pine, and (c) white fir. Year to death $=$ number of years trees survives a wildfire. $\mathrm{Cl}=$ crown injury from fire. Fire-killed tree data were collected from five fires in California that were monitored for 10 years after death

\section{Factors affecting persistence}

Several factors affected individual snag persistence besides time since death (Fig. 1; solid lines). While time since death was the most important factor for all species, accounting for DBH, CI, and PGC allowed us to assess snag persistence on an individual basis. DBH was the most important covariate for white fir, sugar pine, and yellow pine; larger snags persisted longer than smaller snags (Table 3). White fir and sugar pine snags over $50 \mathrm{~cm} \mathrm{DBH}$ and yellow pine snags over $90 \mathrm{~cm} \mathrm{DBH}$ were likely to persist for at least 10 years post mortality (Fig. 3). CI and its interaction with DBH were also significant for white fir and yellow pine. Snags with lower crown injury persisted longer than those with higher crown injury in white fir greater than $50 \mathrm{~cm} \mathrm{DBH}$. Larger white fir and yellow pine snags with lower CI stood longest compared to similarly sized snags with high CI. Smaller white fir and unprotected yellow pine snags with higher CI persisted longer than similarly sized snags with low CI (Figs. 3c and 4). These interactions in pattern occurred around $50 \mathrm{~cm} \mathrm{DBH}$ and $50 \%$ CI for white fir and $30 \mathrm{~cm} \mathrm{DBH}$ and 50\% CI for unprotected yellow pine. Yellow pine smaller than $30 \mathrm{~cm}$ DBH that were protected by green conifers lasted longer than unprotected snags (Fig. 4a, b); however, protection by green conifers dramatically decreased the probability of persistence of large yellow pine snags as CI increased (Fig. $4 a, b)$. Years since death after fire was the only significant covariate for incense-cedar. Incense-cedar that survived longer post fire persisted longer as snags. The random effects of fire or individual variability were not significant in any species. The AIC of the recommended models for all species were within $7 \triangle \mathrm{AIC}$ of the best AIC model.

All covariate models predicted that snags would stand longer than what the time-only models predicted. Sugar pine was particularly affected, with the final $1 \%$ of snags remaining to year 44 in the covariate model versus year 25 in the time-only model (Fig. 1). The covariate model overestimated yellow pine persistence by $31 \%$, but was highly accurate (i.e., within $3 \%$ ) for incense-cedar, sugar pine, and white fir in this dataset (Fig. 2). Model accuracy was assessed on an individual snag level at year 10 and threshold for probability of persistence of $0.5(P<$ 0.5 downed, $P \geq 0.5$ standing). The covariate models for yellow pine, sugar pine, white fir, and incense-cedar predicted $36.1 \%, 58.6 \%, 56.9 \%$, and $87.4 \%$ of snags standing 
a) Yellow pine - unprotected

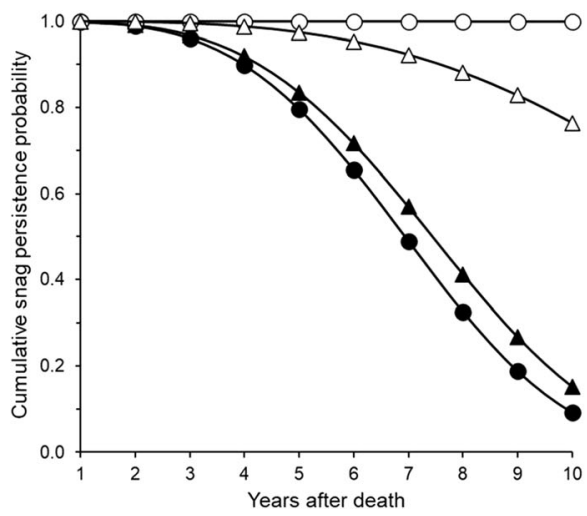

b) Yellow pine - protected

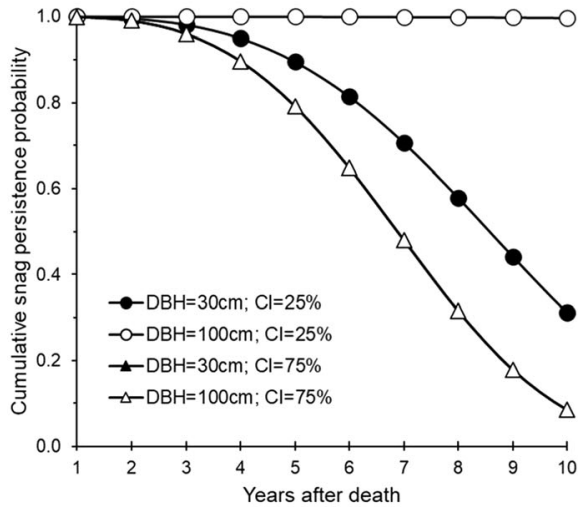

Fig. 4 Yellow pine predicted snag persistence once a tree dies from wildfire ( $1=$ standing; $0=$ downed or $<3.65 \mathrm{~m}$ tall) from covariate model when (a) unprotected by green conifers and (b) protected. Year to death = number of years trees survives a wildfire. $\mathrm{Cl}=\mathrm{crown}$ injury from fire. Fire-killed tree data were collected from five fires in California that were monitored for 10 years after death. In (b), $\mathrm{Cl}=75 \%$ lines overlap for the plotted values

at year 10, respectively. The covariate models accurately predicted individual snag status at year 10 and probability of persistence of 0.5 for $79.2 \%$ of incense-cedar, $75.7 \%$ of sugar pine, $64 \%$ of white fir, and $93.1 \%$ of yellow pine (Table 4).

\section{FFE-FVS snag submodel evaluation}

At 10 years after death, FFE-FVS under-predicted snag persistence by $10 \%$ for incense-cedar and over-predicted persistence in yellow pine (59\%), white fir (20\%), and sugar pine (14\%) (Fig. 2). For all species, FFE-FVS underestimated persistence for the first 3-5 years (Fig. 5). After this period, the FFE-FVS predictions continued to underestimate snag longevity for incense-cedar, but over-predicted for all other species.

\section{Discussion}

Many factors interact to affect wood decay and snag longevity (DeNitto et al. 2000; Lowell et al. 2010; Dunn and

Table 4 Accuracy rates at year 10 and probability of snag persistence cutoff equal to 0.5 for the covariate equations by species. True positive rate is the percentage of snags with a probability of falling greater than 0.5 by year 10 that were observed to fall by year 10 . True negative rate is the percentage of snags with a probability of falling less than 0.5 by year 10 that were observed to be standing at year 10 . Overall accuracy is the percentage of snags that had their status at year 10 correctly predicted by the covariate model at $P=0.5$.

\begin{tabular}{lccl}
\hline & True positive rate & True negative rate & Overall accuracy \\
\hline Incense-cedar & 50.0 & 83.3 & 79.2 \\
Sugar pine & 67.1 & 81.4 & 75.7 \\
White fir & 54.0 & 71.9 & 64.0 \\
Yellow pine & 100.0 & 5.0 & 93.1 \\
\hline
\end{tabular}

Bailey 2015). Snag persistence was species specific in our study, with yellow pine snags falling at a much faster rate than the other species studied. Our results agree with previous findings (Bull 1983; Chambers and Mast 2005; Russell et al. 2006; Dunn and Bailey 2012; Ritchie and Knapp 2014). The differences between species are likely due to a combination of species-specific wood characteristics, xylogphagous insects, and wood decay fungi (Scheffer 1966; Lowell et al. 2010; Dunn and Bailey 2015), although interspecific differences in tree characteristics and injury could play a role (Table 2). Incensecedar was very stable for the first 8 years, as also reported in Ritchie and Knapp (2014) and Ritchie et al. (2013). This is likely attributable to the inherent rot resistance of incense-cedar (Scheffer 1966). Yellow pine is host to many bark and wood-boring beetle species, which can vector fungi and facilitate decay by perforating bark and tunneling into sapwood (Furniss and Carolin 1977). Foraging by woodpeckers can also lead to sapwood cracking and further decay. Hadfield and Magelssen (2006) reported more than three quarters of ponderosa pine fire-killed snag volume was affected by decay within 5 years after death.

Snag age was the strongest predictor of persistence for all species, followed by DBH for yellow pine, sugar pine, and white fir. This concurs with other studies (Keen 1955, Russell et al. 2006, Parish et al. 2010, Dunn and Bailey 2015; Table 1). In those species for which DBH was a significant factor, larger-diameter snags persisted much longer than smaller-diameter snags. This is likely a result of the higher volume of rot-resistant heartwood, the greater percentage of heartwood to sapwood, and the sheer increase in volume in larger snags (Harmon et al. 1986; Lowell et al. 2010). White fir sapwood and heartwood deteriorate quickly after dying, followed by 


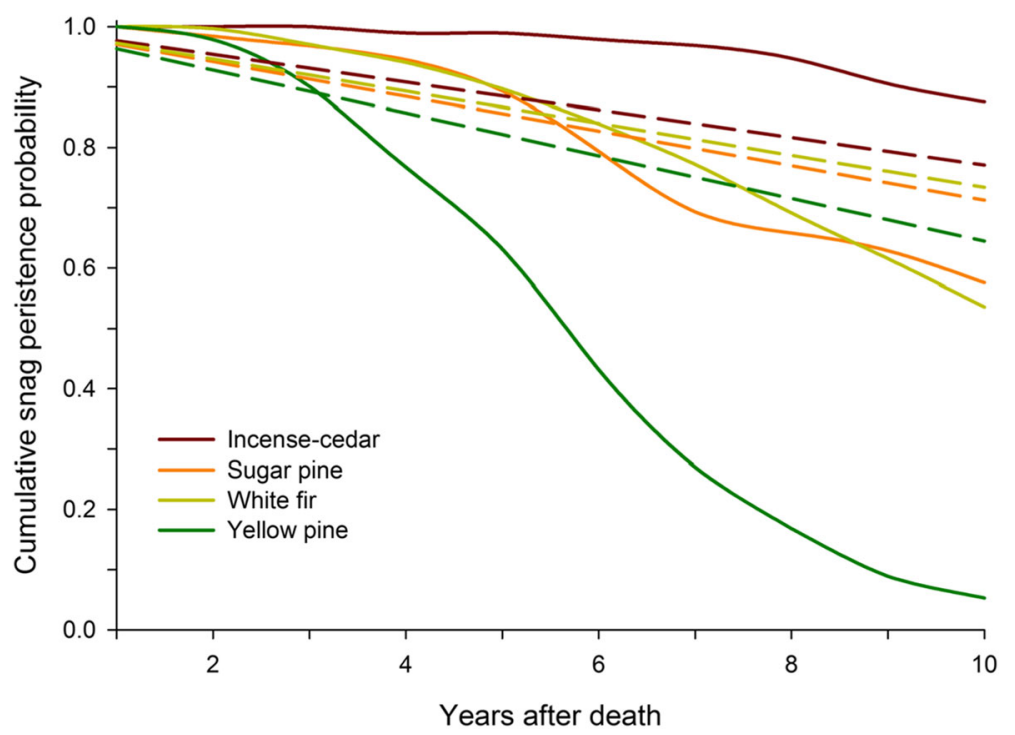

Fig. 5 Observed (solid lines) and FFE-FVS (dashed lines) predicted snag persistence once a tree dies from wildfire $(1=$ standing; $0=$ downed or $<$ $3.65 \mathrm{~m}$ tall) by species. Fire-killed tree data were collected from five fires in California that were monitored for 10 years after death

ponderosa and Jeffrey pine (Kimmey 1955). Therefore, the tendency of larger snags to persist longer than smaller snags, all else equal, may just be due to more volume and the time it takes for that extra volume to decay. Factors such as aspect, elevation, and how long bark is retained on the snag can also influence snag persistence (Kimmey 1955; Harmon et al. 1986). Crown injury was a significant factor in snag persistence in white fir and yellow pine. Trees with lower crown injury persisted longer as snags than those with higher crown injury in white fir greater than $50 \mathrm{~cm} \mathrm{DBH}$ and in yellow pine greater than $30 \mathrm{~cm}$ DBH. Higher crown injury in smaller white fir and unprotected yellow pine led to increased persistence. Additional research is needed to provide mechanistic explanations of snag decay and persistence patterns.

Several studies have shown that snags of some species, such as white fir, may persist longer than other species due to a tendency to break above the downed height threshold and gradually lose height over time (Raphael and White 1984, Everett et al. 1999, Landram et al. 2002, Chambers and Mast 2005; Table 1). This pattern is inconsistent with our results, with average initial break heights below $3.5 \mathrm{~m}$ and the majority of snags breaking at groundline. However, Kimmey (1955) also reported that it was common for ponderosa pine and white fir fire-killed snags to break at ground level. We used $3.65 \mathrm{~m}$ as the height criterion for a snag to move from standing to downed; therefore, most snags converted to downed upon the initial break and we were not able to detect further trends in snag height loss over time. While most other studies of fire-killed snags use shorter height criteria of between 1.5-1.8 m (Table 1), our findings of species differences and the importance of $\mathrm{DBH}$ in determining persistence are still in agreement with these studies.

Choosing a snag persistence model will depend on the intended use and tolerance of accuracy and cost. The FFE-FVS models over-predicted snag longevity for sugar pine, white fir, and yellow pine, and under-predicted snag persistence for incense-cedar at year 10. The large over-prediction of yellow pine snag persistence by FFEFVS suggests that caution is needed when using this software to estimate snag longevity after fire. The covariate models were more accurate than FFE-FVS, but not as accurate in predicting overall snag persistence as the time-only models. This is due to the increased difficulty in modeling behavior at the individual snag level rather than at the stand level. Only 12 incense-cedars had fallen by the end of the observation period. Although this is enough to develop a reasonable model, in future studies, incense-cedar should be followed for a longer period of time to assess the accuracy of these models past 10 years.

When choosing a basis for predicting snag persistence, it is important to note the limitations of a particular study. We summarized published studies evaluating firekilled snags of the species we assessed for comparison with our results (Table 1). Here, we had right-censored data, only assessed trees that survived at least one year post fire, did not assess unburned trees, and sampled a small number of downed incense-cedar. All studies in Table 1 also contain censored data. Many did their initial snag survey several years post fire, assuming all standing (and in some cases, downed) snags at the time of the measurement were killed in the fire (Dahms 1949; 
Raphael and White 1984; Raphael and Morrison 1987; Morrison and Raphael 1993; Everett et al. 1999; Smith 1999; Chambers and Mast 2005; Russell et al. 2006; Bagne et al. 2008; Dunn and Bailey 2012). Only five studies compared burned and unburned snags (Raphael and White 1984; Raphael and Morrison 1987; Morrison and Raphael 1993; Chambers and Mast 2005; Bagne et al. 2008). Several studies had low sample sizes or inadequate range distributions in one or more subsets of the data (Raphael and White 1984; Everett et al. 1999; Smith 1999; Chambers and Mast 2005; Bagne et al. 2008). Some studies did not follow individual snags, but rather inventoried or censused snags in the study area (Dahms 1949; Raphael and White 1984). Lastly, longitudinal data of natural phenomena are almost certain to have some confounding factors as well as variables that are strongly correlated; these can cause statistical use and interpretation challenges. As with virtually any model application, it is important to choose a model that was developed from data that most closely matches the tree and site conditions in question.

\section{Conclusions and management implications}

Snags and downed logs are essential to forest ecosystems, providing numerous ecosystem benefits, but also contributing to fuel loading (Dunn and Bailey 2015). This study provides post-fire snag persistence information for five conifer species to aid land managers in meeting snag-related forest objectives. Snag age and $\mathrm{DBH}$ were the strongest predictors of fire-killed snag persistence. For all species, smaller-diameter snags fell more quickly than larger snags, with white fir and sugar pine snags over $50 \mathrm{~cm} \mathrm{DBH}$ and yellow pine over $90 \mathrm{~cm}$ $\mathrm{DBH}$ predicted to persist much longer than smaller snags. Incense-cedar snags were fairly stable, but they are not as widely used by wildlife as the other species studied (Thomas 1979; Morrison et al. 1987; Bagne et al. 2008) and therefore may not be the preferred tree species for snag retention for wildlife objectives in a postfire management scenario. However, incense-cedar could be useful for other objectives such as carbon storage. White fir and sugar pine snags both persisted for an extended time on the landscape and are moderately used by wildlife (Thomas 1979; Morrison et al. 1987; Ganey and Vojta 2004; Bagne et al. 2008). Although yellow pine snags are widely used by wildlife, virtually all yellow pine fell within 10 years of dying. In addition, we found FFEFVS greatly over-predicted yellow pine fire-killed snag persistence and recommend revising the equations in the software to reflect the consistently reported finding of fast fall rates in yellow pine. Snags and logs provide numerous ecosystem benefits (e.g., wildlife habitat, nutrient cycling, germination microsites), but also can potentially increase future fire severity. Our results can be used to inform post-fire snag management considerations.

\section{Acknowledgements}

We greatly appreciate the support and cooperation from personnel on the Eldorado, Lassen, Sequoia, and Tahoe national forests. We thank B. Borys, J. Egan, E. Frolli, R. Mahnke, J. McFarland, and S. Muse for their assistance with field data collection. The comments of three anonymous reviewers improved a previous version of the manuscript.

\section{Funding}

Funding was provided by the US Forest Service, Forest Health Protection, and US Forest Service, Rocky Mountain Research Station.

Availability of data and materials

Available at request of corresponding author.

\section{Authors' contributions}

LMG analyzed data; DRC conceived of the study, collected data, and edited the text; SMH assisted with study design and data analysis. LMG and SMH co-wrote the manuscript. All authors read and approved the final manuscript.

Ethics approval and consent to participate

Not applicable.

Consent for publication

The authors consent to publication.

\section{Competing interests}

The authors declare that they have no competing interests.

\section{Publisher's Note}

Springer Nature remains neutral with regard to jurisdictional claims in published maps and institutional affiliations.

\section{Author details}

'USDA Forest Service, Rocky Mountain Research Station, Fire, Fuel, and Smoke Science Program, 5775 US Highway 10 W, Missoula, Montana 59808, USA. ${ }^{2}$ USDA Forest Service, Forest Health Protection, Northeastern California Shared Service Area, 2550 Riverside Drive, Susanville, California 96130, USA.

Received: 4 April 2018 Accepted: 14 September 2018

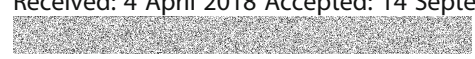

\section{References}

Anderson, D.R., and K.P. Burnham. 2002. Avoiding pitfalls when using information-theoretic methods. The Journal of Wildlife Management 66 (3): 912-918. https://doi.org/10.2307/3803155.

Bagne, K.E., K.L. Purcell, and J.T. Rotenberry. 2008. Prescribed fire, snag population dynamics, and avian nest site selection. Forest Ecology and Management 255 (1): 99-105. https://doi.org/10.1016/j.foreco.2007.08.024.

Barrett, J.W., P.M. McDonald, F. Ronco Jr., and R.A. Ryker. 1980. Interior ponderosa pine SAF Type 237. In Forest cover types of the United States and Canada, ed. F.H. Eyre, 114-115. Washington, D.C., USA.

Brais, S., D. Paré, and C. Lierman. 2006. Tree bole mineralization rates of four species of the Canadian eastern boreal forest: implications for nutrient dynamics following stand-replacing disturbances. Canadian Journal of Forest Research 36: 2331-2340. https://doi.org/10.1139/×06-136.

Bull E.L. 1983. Longevity of snags and their use by woodpeckers. In Snag habitat management: proceedings of the symposium. USDA Forest Service General Technical Report RM-GTR-99, technical coordinators, J.W. Davis, G.A. Goodwin, and R.A. Ockenfels, 64-67. Fort Collins, Colorado, USA: Rocky Mountain Forest and Range Experiment Station.

Bull, E.L., C.G. Parks, and T.R. Torgersen. 1997. Trees and logs important to wildlife in the Interior Columbia River Basin, USDA Forest Service General Technical Report PNW-GTR-391. Portland, Oregon, USA: Pacific Northwest Research Station. 
Bunnell, F.L. 2013. Sustaining cavity-using species: patterns of cavity use and implications to forest management. ISRN Forestry 2013:article 457698:33. https://doi.org/10.1155/2013/457698.

Bunnell, F.L., and L.L. Kremsater. 1990. Sustaining wildlife in managed forests. Northwest Environmental Journal 6 (2): 243-269.

Bunnell, F.L., E. Wind, M. Boyland, and I. Houde. 2002. Diameters and heights of trees with cavities: their implications to management. In Proceedings of the symposium on the ecology and management of dead wood in Western forests, USDA Forest Service General Technical Report PSW-GTR-181, ed. W.F. Laudenslayer, P.J. Shea, B.E. Valentine, C. Weatherspoon, L. Phillip, and E. Thomas, 2-4. Albany, California, USA: Pacific Southwest Research Station.

Burnham, K.P., D.R. Anderson, and K.P. Huyvaert. 2011. AlC model selection and multimodel inference in behavioral ecology: some background, observations, and comparisons. Behavioral Ecology and Sociobiology 65 (1): 23-35. https:// doi.org/10.1007/s00265-010-1029-6.

California Department of Fish and Wildlife. 2014. CWHR version 9.0 personal computer program. Sacramento, California, USA: California Department of Fish and Wildlife, California Interagency Wildlife Task Group.

Chambers, C.L., and J.N. Mast. 2005. Ponderosa pine snag dynamics and cavity excavation following wildfire in northern Arizona. Forest Ecology and Management 216 (1): 227-240.

Dahms, W.G. 1949. How long do ponderosa pine snags stand? USDA Forest Service Research Note PNW-RN-57. Portland, Oregon, USA: Pacific Northwest Forest and Range Experiment Station.

DeNitto, G., B. Cramer, K. Gibson, B. Lockman, T. McConnell, L. Stipe, N. Sturdevant, and J. Taylor. 2000. Survivability and deterioration of fire-injured trees in the northern Rocky Mountains: a review of the literature. Missoula, Montana, USA: USDA Forest Service Forest Health Protection.

Dunn, C.J., and J.D. Bailey. 2012. Temporal dynamics and decay of coarse wood in early seral habitats of dry-mixed conifer forests in Oregon's Eastern Cascades. Forest Ecology and Management 276: 71-81. https://doi.org/10.101 6/j.foreco.2015.01.002

Dunn, C.J., and J.D. Bailey. 2015. Modeling the direct effects of salvage logging on long-term temporal fuel dynamics in dry-mixed conifer forests. Forest Ecology and Management 341: 93-109. https://doi.org/10.1016/j.foreco.2015. 01.002

Everett, R., J. Lehmkuhl, R. Schellhaas, P. Ohlson, D. Keenum, H. Riesterer, and D. Spurbeck. 1999. Snag dynamics in a chronosequence of 26 wildfires on the east slope of the Cascade Range in Washington state, USA. International Journal of Wildland Fire 9 (4): 223-234. https://doi.org/10.1071/WF00011.

Furniss, R.L., and V.M. Carolin. 1977. Western forest insects. Washington, D.C., USA USDA Forest Service. https://doi.org/10.5962/bhl.title.131875.

Ganey, J.L. 2016. Recommendations for snag retention in Southwestern mixedconifer and ponderosa pine forests: history and current status. Wildlife Society Bulletin 40 (1): 192-201. https://doi.org/10.1002/wsb.609.

Ganey, J.L., and S.C. Vojta. 2004. Characteristics of snags containing excavated cavities in northern Arizona mixed-conifer and ponderosa pine forests. Forest Ecology and Management 199 (2-3): 323-332.

Garber, S.M., J.P. Brown, D.S. Wilson, D.A. Maguire, and L.S. Heath. 2005. Snag longevity under alternative silvicultural regimes in mixed-species forests of central Maine. Canadian Journal of Forest Research 35 (4): 787-796. https:// doi.org/10.1139/x05-021.

Hadfield, J., and R. Magelssen. 2006. Wood changes in fire-killed tree species in eastern Washington, USDA Forest Service, Okanogan-Wenatchee National Forest. Wenatchee, Washington, USA: USDA Forest Service.

Harmon, M.E., J.F. Franklin, F.J. Swanson, P. Sollins, S.V. Gregory, J.D. Lattin, N.H. Anderson, S.P. Cline, N.G. Aumen, J.R. Sedell, G.W. Lienkaemper, K. Cromack, and K.W. Cummins. 1986. Ecology of coarse woody debris in temperate ecosystems. In Advances in Ecological Research, ed. A. MacFadyen and E.D. Ford, vol. 15, 133-302. Cambridge, Massachusetts, USA: Academic Press.

Harrington, M.G. 1996. Fall rates of prescribed fire-killed ponderosa pine, USDA Forest Service Research Paper INT-RP-489. Ogden, Utah, USA: Intermountain Research Station.

Hicks, L.L. 1983. Snag management: options and incentives for private landowners. In Snag habitat management: proceedings of the symposium, USDA Forest Service General Technical Report RM-GTR-99, technical coordinators. J.W. Davis, G.A. Goodwin, and R.A. Ockenfels, 60-63. Fort Collins, Colorado, USA: Rocky Mountain Forest and Range Experiment Station.
Hood, S.M., S. Smith, and D. Cluck. 2010. Predicting tree mortality for five California conifers following wildfire. Forest Ecology and Management 260 (5): 750-762. https://doi.org/10.1016/j.foreco.2010.05.033.

Keen, F. 1955. The rate of natural falling of beetle-killed ponderosa pine snags. Journal of Forestry 53 (10): 720-723.

Kimmey, J.W. 1955. Rate of deterioration of fire-killed timber in California, USDA Forest Service Circular No. 962. Washington, D.C., USA: California Forest and Range Experiment Station.

Kleinbaum, D.G., and M. Klein. 2010. Survival analysis. Vol. 3. New York, New York, USA: Springer.

Krankina, O.N., and M.E. Harmon. 1995. Dynamics of the dead wood carbon pool in northwestern Russian boreal forests. Water, Air, and Soil Pollution 82: 227238. https://doi.org/10.1007/BF01182836

Landram F.M., W.F. Laudenslayer Jr., and T. Atzet. 2002. Demography of snags in eastside pine forests of California. In Proceedings of the symposium on the ecology and management of dead wood in Western forests, USDA Forest Service General Technical Report PSW-GTR-181, technical coordinators, W.F. Laudenslayer, P.J. Shea, B. Valentine, C.P. Weatherspoon, and T.E. Lisle, 605620. Albany, California, USA: Pacific Southwest Research Station.

Lowell, E.C., V. Rapp, R. Haynes, and C. Cray. 2010. Effects of fire, insect, and pathogen damage on wood quality of dead and dying Western conifers, USDA Forest Service General Technical Report PNW-GTR-816. Portland, Oregon, USA: Pacific Northwest Research Station.

Lyon, L.J. 1977. Attrition of lodgepole pine snags on the Sleeping Child Burn, Montana, USDA Forest Service Research Note INT-RN-219. Ogden, Utah, USA: Intermountain Forest and Range Experiment Station.

Marcot, B. 1992. Snag recruitment simulator version 3.1. Pacific Northwest Region, Portland, Oregon, USA: USDA Forest Service.

McClelland, B.R., S.S. Frissell, W.C. Fischer, and C.H. Halvorson. 1979. Habitat management for hole-nesting birds in forests of western larch and Douglasfir. Journal of Forestry 77 (8): 480-483.

Mellen K., and A. Ager. 2002. A coarse wood dynamics model for the western Cascades. In Proceedings of the symposium on the ecology and management of dead wood in Western forests, USDA Forest Service General Technical Report PSW-GTR-181, technical coordinators, W.F. Laudenslayer, P.J. Shea, B. Valentine, C.P. Weatherspoon, and T.E. Lisle, 503-516. Albany, California, USA: Pacific Southwest Research Station.

Mitchell, R.G., and H.K. Preisler. 1998. Fall rate of lodgepole pine killed by the mountain pine beetle in central Oregon. Western Journal of Applied Forestry 13 (1): 23-26.

Morrison, M.L., and M.G. Raphael. 1993. Modeling the dynamics of snags. Ecological Applications 3 (2): 322-330. https://doi.org/10.2307/1941835.

Morrison, M.L., K.A. With, I.C. Timossi, W.M. Block, and K.A. Milne. 1987. Foraging behavior of bark-foraging birds in the Sierra Nevada. The Condor 89 (1): 201204. https://doi.org/10.2307/1368782

Parish, R., J.A. Antos, P.K. Ott, and C.M. Di Lucca. 2010. Snag longevity of Douglasfir, western hemlock, and western redcedar from permanent sample plots in coastal British Columbia. Forest Ecology and Management 259 (3): 633-640. https://doi.org/10.1016/j.foreco.2009.11.022

Peterson, D.W., E.K. Dodson, and R.J. Harrod. 2015. Post-fire logging reduces surface woody fuels up to four decades following wildfire. Forest Ecology and Management 338: 84-91. https://doi.org/10.1016/j.foreco.2014.11.016.

Qi, J. 2009. Comparison of proportional hazards and accelerated failure time models, Thesis. Saskatoon, Saskatchewan, Canada: University of Saskatchewan.

R Development Core Team. 2016. R: a language and environment for statistical computing. Vienna, Austria: R Foundation for Statistical Computing.

Raphael, M.G., and M.L. Morrison. 1987. Decay and dynamics of snags in the Sierra Nevada, California. Forest Science 33 (3): 774-783.

Raphael, M.G., and M. White. 1984. Use of snags by cavity-nesting birds in the Sierra Nevada. Wildlife Monographs 86: 3-66.

Reinhardt, E., and N. Crookston. 2003. The fire and fuels extension to the forest vegetation simulator, USDA Forest Service General Technical Report RMRSGTR-116. Ogden, Utah, USA: Rocky Mountain Research Station.

Ritchie, M.W., and E.E. Knapp. 2014. Establishment of a long-term fire salvage study in an interior ponderosa pine forest. Journal of Forestry 112 (5): 395 400. https://doi.org/10.5849/jof.13-093.

Ritchie, M.W., E.E. Knapp, and C.N. Skinner. 2013. Snag longevity and surface fuel accumulation following post-fire logging in a ponderosa pine dominated forest. Forest Ecology and Management 287: 113-122. https://doi.org/10.1016/ j.foreco.2012.09.001. 
Russell, R.E., V.A. Saab, J.G. Dudley, and J.J. Rotella. 2006. Snag longevity in relation to wildfire and postfire salvage logging. Forest Ecology and Management 232 (1): 179-187. https://doi.org/10.1016/j.foreco.2006.05.068.

Ryan K.C. 1982. Techniques for assessing fire damage to trees. In Proceedings of the symposium: fire, its field effects, ed. J. Lotan, 1-11. Jackson, Wyoming, USA: Intermountain Fire Council, 19-21 October 1982.

Scheffer, T.C. 1966. Natural resistance of wood to microbial deterioration. Annual Review of Phytopathology 4 (1): 147-168. https://doi.org/10.1146/annurev.py. 04.090166.001051.

Schmid, J., S. Mata, and W. McCambridge. 1985. Natural falling of beetle-killed ponderosa pine, USDA Forest Service Research Note RM-454. Fort Collins, Colorado, USA: Rocky Mountain Forest and Range Experiment Station.

Smith, H.Y. 1999. Assessing longevity of ponderosa pine (Pinus ponderosa) snags in relation to age, diameter, wood density and pitch content, Thesis. Missoula, USA: University of Montana.

Tappeiner, J.C. 1980. Sierra Nevada mixed conifer SAF Type 243. In Forest cover types of the United States and Canada, ed. F.H. Eyre, 118-119. Washington, D. C., USA: Society of American Foresters.

Thomas, J.W. 1979. Wildlife habitats in managed forests-the Blue Mountains of Oregon and Washington. USDA Forest Service Agriculture Handbook No. 553, Washington, D.C, USA

USDA Forest Service. 1992. Appendix O-wildlife habitat capability models for management indicator species, land and resource management plan, Lassen National Forest. Susanville, California, USA: Lassen National Forest.

\section{Submit your manuscript to a SpringerOpen ${ }^{\circ}$ journal and benefit from:}

- Convenient online submission

- Rigorous peer review

- Open access: articles freely available online

- High visibility within the field

- Retaining the copyright to your article

Submit your next manuscript at $\boldsymbol{\nabla}$ springeropen.com 